\title{
ILCEA
}

Revue de l'Institut des langues et cultures

d'Europe, Amérique, Afrique, Asie et Australie

$24 \mid 2015$

Lire et écrire ensemble

\section{Manos desobedientes}

Noé Jitrik

URL: http://journals.openedition.org/ilcea/3678

DOI: 10.4000/ilcea.3678

ISSN: 2101-0609

Editor

UGA Éditions/Université Grenoble Alpes

Edición impresa

ISBN: 978-2-84310-313-1

ISSN: $1639-6073$

Referencia electrónica

Noé Jitrik, « Manos desobedientes », ILCEA [En línea], 24 | 2015, Publicado el 02 noviembre 2015, consultado el 22 septiembre 2020. URL : http://journals.openedition.org/ilcea/3678 ; DOI : https:// doi.org/10.4000/ilcea.3678

Este documento fue generado automáticamente el 22 septiembre 2020.

(C) ILCEA 


\title{
Manos desobedientes
}

\author{
Noé Jitrik
}

1 "La chimenea llena de símbolos y de animales fabulosos del Arte de adornar las chimeneas... es muy propia de la mano que dibujó los leones gigantescos de las planchas de Prisiones". Esta frase, que está como al pasar en el extraordinario ensayo de Marguerite Yourcenar, "El negro cerebro de Piranesi", quizás sin ir más lejos que la locución corriente, "tener buena mano", o como un mero escalón en una escala discursiva ascendente - un sostenuto infatigable al mismo tiempo- me remite, tal vez porque estoy predispuesto a ver un poco más allá de lo inmediato, a una reflexión que me parece que tiene consecuencias. Gira en torno a la imagen de esa "mano" que, porque dibujó, posee una cualidad que no es sólo la obvia de sus virtudes mecánicas. La mención de la mano no se detiene, por lo tanto, en el mero elogio de su capacidad. En otra ocasión me detuve en eso que lo desborda. La imagen me regresa y siento que en su momento me fijé un límite que ahora tal vez pueda superar.

2 La mano, pensé, no parece autónoma, no se mueve por sí sola, como lo hace cuando el cuerpo es afectado por el mal de Parkinson; se mueve porque el cerebro le imparte una orden y si logra hacer cosas -ese hacer al que está en principio destinada- es porque confluye en ella y orienta su movimiento un haz de impulsos que salen de ese lugar privilegiado; pero, a su vez, no hay tales impulsos si no responden a un principio que radica también en el cerebro pero que no es sólo nervioso sino una instancia superior: la podemos llamar "psicológica", a sabiendas de que estamos simplificando, lo que no cierra la posibilidad de entender todo lo que puede estar contenido en esa designación: voluntad, sentimientos, sensaciones, intención, raciocinio, etc., que, sin rigor designativo alguno, podemos designar como cualidades o capacidades de diferente amplitud, según los sujetos, sus historias, sus, igualmente, capacidades de utilización. Dicho de otro modo, todas esas cualidades confluyen en un punto que de una manera $u$ otra las conjuga y sintetiza -llamamos "imagen" a ese conglomerado- y ordena y la mano, finalmente, ejecuta, así como lo hacen, en relación con tipos particulares de órdenes, otros órganos del cuerpo.

3 Así, pues, en principio, un artista, no sólo Piranesi, todos, cuenta con su mano para cumplir con lo que el cerebro indica en forma de una imagen a concretar en otro lugar 
y el cerebro, a su vez, opera respondiendo a lo que resulta del conjunto de tales cualidades. De este modo, se podría pensar que la mano no haría nada por sí misma y que basta que exista una orden, en otras palabras una intención o una indicación para que no sólo se ponga en movimiento sino que dé forma a lo que ese cerebro desea que tome forma.

4 La indicación o la orden no basta para explicar lo que sucede: se diría que son instrumentos de un querer que reside en otro campo - un querer que quiere concretar o formalizar y que será la mano quien lo ejecute. De modo que entre imagen mental y, en este caso, dibujo realizado, se tiende una suerte de puente que se termina por atravesar, de una orilla, mental -la podemos llamar imaginario- a otra orilla, física una obra. Extraordinario proceso que se suele llevar a cabo muy naturalmente, con esfuerzo a veces -el artista es siempre un insatisfecho-, con felicidad otras, pero siempre sintiendo que eso tiene un sentido, tanto que lo producido es vivido como un pleno, como un estallido que significa en sí mismo y que convierte en significado a quien se acerca a ello.

5 Eso que llamamos imaginario no es sólo un lugar de gestación de las imágenes, como si fueran la materia que el cerebro le ordena a la mano que transforme según determinados códigos y en determinados campos; en su interior -como si fuera un espacio de límites y contornos precisos- actúa una suerte de mecanismo de alimentación que a su vez se nutre de lo que se va recogiendo a lo largo de la existencia. Experiencias, situaciones, pensamientos, emociones, sueños, fantasías, reflexiones que, sometidas a determinados procesos de selección, configuran eso que se llama "memoria" y a lo cual se acude para recuperar unas u otras, según lo ordena un deseo, traducido por una intención, y que, en segunda instancia, constituyen el material que va a ser dirigido a una mano que deberá darle una forma diferente, ese final de proceso que se denomina "obra".

6 Ese circuito, que parece muy natural, cuyo punto de partida es un saber básico adquirido por aprendizaje o por comparación, y hasta cierto punto previsible, va constituyendo a su vez un saber más complejo, superior se diría en relación con el básico, ese saber del artista, pintor, escultor, músico o escritor a quien cada operación de este tipo se le va acumulando en una suerte de colchón de experiencia intrínseca que le permite seguir produciendo puesto que luego de cada acto, llamado comúnmente creativo, "sabe" un poco más acerca de lo que está haciendo o se propone hacer o le falta hacer.

7 Pero la mano casi nunca obedece, en escritura, en música y con más razón en escultura y en pintura: "La debilidad de mi mano temblorosa que no quiere obedecer como yo lo quisiera" dice el pintor Poussin y Gaëtan Picon, que recoge la expresión, añade: "Y a pesar de ello la obra será bella." Entre ambas frases se establece ese conflicto de virtualidades: la desobediencia de la mano genera la belleza perceptible. Así ocurre en la escritura cuando se trata de pasar al papel o a sus equivalentes una imagen pensada, amasada palabra por palabra en un instante previo de imaginación o de ensoñación, con un prurito transcriptivo de extrema fidelidad: casi invariablemente el intento se ve frustrado, la literalidad es imposible, más o menos palabras actúan por cuenta propia y si la fidelidad tenía un costado ético la transcripción que la traiciona falsea aquello tan perfecto y genera algo diferente, lo único que nos permite pensar en qué pasó de un lugar al otro, de la orden a la ejecución. ¿Escuchamos siempre lo mismo si el piano lo toca Rubinstein o lo toca Brendel, aunque ambos interpreten la misma partitura? ¿Son 
infieles al texto original que están ejecutando o simplemente sus respectivas manos, que impulsan las cuerdas, poseen diferentes órdenes de saber de lo mismo que ambos están haciendo?

8 Se trata, entonces, de órdenes de saber y, como siempre, dichos saberes residen en la memoria: la mano tiene memoria y a ella acude en el preciso momento en que tiene que responder y si bien no puede sino desobedecer tampoco lo hace del todo, conserva de la orden el sentido general y entiende, porque está dotada de memoria, que le está permitido el matiz, la inflexión que no sólo le permite reconocerse en su caudal de saber sino también identificar, más que a la imagen que transmite, al sujeto entero que de este modo, por esa desobediente inflexión se presenta como es, como lo que lo pone en el mundo en tanto diferente, en tanto se piensa y se quiere uno y singular junto a otros igualmente, y por las mismas razones, unos y singulares.

Si por una parte esta "lectura" de la posición de la mano es sólo una hipótesis que como tal puede ser refutada o rechazada o, en el mejor de los casos, aceptada, también podría, si es así, generalizarse a otras zonas corporales; extremando las cosas, la idea tan corriente de "hábitos" aplicable, como expediente inmediato, en cualquier terapéutica y aun en toda forma de vida, a las vísceras o incluso a esa vieja y sabia consigna, "la función hace al órgano", en la que se apoyan sin distinción las virtudes de las gimnásticas, viene a corroborar su sensatez, no sólo por los beneficios que brinda sino porque ratifica que se trata de modos de memoria plurales e inesperados: un hueso roto, y reparado, recuerda siempre el trauma, una bacteria instalada genera en el recinto al que llega una respuesta que, en ciertos casos, tiene la aterradora forma de una producción del inconciente.

Aun así, no se trataría en esta aproximación de una teoría general de la memoria sino, tan sólo y restringidamente, a lo que resulta de lo más visible, la mano, las otras expresiones corporales exigirían un discurso con otra fundamentación epistemológica o, respetando los límites de éste, simplemente "más" epistemológica. De este modo, y regresando al punto de partida, no sería totalmente arbitrario ni excesivo considerar esta avenida que se abre en la vinculación "mano operatoria-memoria intrínseca" con los alcances que tiene el concepto de "diferencia", de valor explicatorio para toda performancia.

11 Si bien tal vez no lo hayan "pensado" de la misma manera es posible que hayan sentido eso mismo respecto de la mano, pero en términos de magia o, mejor, de reducto significante, los pintores anatomistas, esos que sobre todo en el Renacimiento, cuando comienzan las miradas sobre el cuerpo, lo desnudan, lo celebran, lo despedazan, lo estudian: en la obra de Grünewald o en las infinitas interpretaciones de las manos de Cristo en la cruz vibra una significación que va más allá de la representación necesaria, a veces son más que los rostros, explícitamente expresivos, y dicen más que los depósitos de color en las telas o en los objetos inanimados. El sufrimiento está en los rostros, sin duda, pero las manos, sus nervaduras, muestran en ocasiones una fuerza que acaso va en otra dirección, como si poseyeran una memoria cargada, de sufrimiento por cierto, más por la imploración que por la lastimadura, como la que se precipita en los dramáticos estudios de Chillida, cuyos dibujos de manos en diversos momentos y posiciones parecen descargas de una memoria de múltiples formas, como si estuvieran gritando silenciosas aquello que encierran y que intenta salir. Tal vez lo hayan sentido o entendido los pintores japoneses cuando de pie, desde lo alto, y manejando profusos pinceles, hacían fluir la energía, poniendo en la mano todo el peso 
y la historia del cuerpo, en la certeza de que la distancia que establecían entre la idea y el papel generaba figuras que si no estaban del todo lejos de la idea la matizaban y vinculaban el producto con el universo de saber depositado en la mano. Y que opera, según lo pude sugerir -en una observación que dio entrada a esta preocupación- en los retratos que sobre la imagen de Pessoa trazó con admirable diversidad Hermenegildo Sábat, todos diferentes, todos guiados por una misma memoria que es fiel e infiel al mismo tiempo, admirablemente, a la imagen original, su aura y su historia.

12 Hablamos del concepto de diferencia; es, se sabe, operatorio, sin diferencia sólo hay masa y, correlativamente, admitirlo es entrar en los secretos de lo que se conoce o designa como "estilo" o, más propiamente, "estilos" que no sólo permiten reconocer e identificar obras sino también a sus productores. Barthes señalaba que el "estilo" no es el campo de las decisiones -que vinculaba con la "escritura", acción, noción o concepto que canalizaría la "intención" y produciría de ahí la "significación- sino que está ya determinado, lo mismo que la lengua. ¿No será que el estilo, que es lo que identifica una obra y a quien la produce, reside en la mano que no hace sino lo que su propia memoria le indica? Y porque vuelca la diferencia y la satura de su saber se traduce en una general inscripción - por no hablar de otras acciones- que ejecuta mediante un instrumento que, no por azar se llamaba en el mundo latino "stylus", palabra traslaticia, por cierto, que designa las particularidades pero ya no los instrumentos, reemplazados incesantemente en toda la historia de la cultura pero siempre ligados a la mano que los emplea y, a través de ellos, vincula su propia memoria con la memoria de aquello a lo que le está dando forma. 